\title{
Photoinhibition and recovery after selective short-term exposure to solar radiation of five chlorophyll $c$-containing marine microalgae
}

\section{Fotoinhibición y recuperación de cinco microalgas marinas con clorofila $c$ tras breves exposiciones selectivas a la radiación solar}

\author{
Olimpio Montero* \\ Cristina Sobrino \\ Griselda Parés \\ Luis M. Lubián
Instituto de Ciencias Marinas de Andalucía (CSIC)
Avda. República Saharaui s/n
11510 - Puerto Real, Cádiz, Spain
*E-mail: olimpio.montero@icman.csic.es \\ Recibido en enero de 2001; aceptado en marzo de 2002
}

\begin{abstract}
The differential sensitivity of five chlorophyll $c$-containing marine microalgae to different components of solar radiation, e.g. photosynthetic active radiation (PAR), ultraviolet-A (UV-A) and ultraviolet-B (UV-B), was investigated in an exclusion experiment involving exposure to PAR, PAR+UV-A and PAR+UV-A+UV-B (P-, PA- and PAB-treatment, respectively) for 20 min and subsequent recovery for up to $24 \mathrm{~h}$ in dim light. The decrease in the variable to maximal chlorophyll fluorescence ratio $\left(F_{v} / F_{m}\right)$ was used as indicator of photoinhibition. Changes in photosynthetic oxygen production, cell densities and pigment contents were also ascertained. The ratio $F_{v} / F_{m}$ decreased in all the algae after exposure, but differences were found between the algae and the treatments. In relation to the inhibition extent, Chaetoceros sp. was the least affected alga in each treatment, while Phaeodactylum tricornutum was the most sensitive. Data of $F_{v} / F_{m}$ during recovery fitted well to a sigmoid exponential function, and calculated constants were used to quantify the particular recovery rate of each alga. In general, recovery time did not show a direct relationship with the extent of inhibition. The highest recovery rate was shown by $P$. tricornutum cells exposed to only PAR, and the lowest by Isochrysis galbana cells exposed to PAB. There were no losses of cell density at the end of the recovery period in relation to the initial cell density in any of the algae. Photosynthetic oxygen production dropped in the five algae in all treatments and showed a similar evolution pattern to $F_{v} / F_{m}$ during recovery, except for $P$. tricornutum and Amphidinium sp. Results of this study point out that capacity for photosynthesis inhibition is specific for each alga and, consequently, it should be taken into consideration for a reliable assessment of differential sensitivity to ultraviolet radiation among diverse marine phytoplanktonic species.
\end{abstract}

Keywords: marine microalgae, ultraviolet radiation, photosynthesis, photoinhibition, chlorophyll fluorescence.

\section{Resumen}

Se investigaron las diferencias de sensibilidad en cinco microalgas marinas conteniendo clorofila $c$, en relación a los diferentes componentes de la radiación solar, v.g. radiación fotosintéticamente activa (PAR), ultravioleta-A (UV-A) y ultravioleta-B (UV-B), en un experimento con exclusión selectiva de cada componente que incluyó exposición a PAR, PAR+UVA y PAR+UV-A+UV-B (tratamientos P, PA y PAB, respectivamente) durante 20 min y la subsiguiente recuperación en luz tenue por hasta $24 \mathrm{~h}$. Como indicador de fotoinhibición se usó el descenso en el cociente entre fluorescencia variable y fluorescencia máxima de la clorofila $\left(F_{v} / F_{m}\right)$. También se determinaron los cambios en la producción fotosintética de oxígeno, densidades de células y contenido de pigmentos. Tras la exposición, $F_{v} / F_{m}$ disminuyó en todas las algas pero se encontraron diferencias entre las distintas algas y tratamientos. En cuanto al alcance de la inhibición, Chaetoceros sp. fue el alga menos afectada en cada tratamiento, mientras que Phaedactylum tricornutum fue la más sensible. Los datos de $F_{v} / F_{m}$ durante el periodo de recuperación se ajustaron bien a una función exponencial sigmoidea, y las constantes calculadas se usaron para cuantificar la velocidad de recuperación de cada alga. En general, el curso temporal de la recuperación no presentó una relación directa con el grado de inhibición. La tasa de recuperación más alta fue la de las células de $P$. tricornutum expuestas solamente a PAR y, la más baja fue la de las células de Isochrysis galbana expuestas a PAB. En ninguna de las algas hubo pérdidas significativas de densidad de células al final del periodo de recuperación en relación a la densidad inicial. En todos los tratamientos la producción fotosintética de oxígeno decayó en las cinco algas, mostrando un patrón de evolución similar a $F_{v} / F_{m}$ durante la recuperación, excepto para $P$. tricornutum y Amphidinium sp. Los resultados de este estudio muestran que la capacidad de recuperación tras inhibición de la 
fotosíntesis es específica para cada alga y, consecuentemente, este hecho debería ser tenido en cuenta para una valoración realista del grado de sensibilidad a la radiación ultravioleta entre las diversas especies de fitoplancton marino.

Palabras clave: microalgas marinas, radiación ultravioleta, fotosíntesis, fotoinhibición, fluorescencia de la clorofila.

\section{Introduction}

The diversity of phytoplankton communities is extremely high in seawater and, in particular, in the upper ocean, so that primary productivity results from contributions of the ensemble of a community. Primary productivity can then be impinged by any change in environmental factors, either by reducing photosynthetic capacity as a whole or by modifying the species composition. There is evidence that the increasing levels of ultraviolet radiation (UVR) that reach the Earth's surface nowadays might operate in such a sense (Häder, 1993). Specifically, the component of UVR ranging between 280 and 315 $\mathrm{nm}$, the so called ultraviolet-B (UV-B), has been pointed out to impair underwater photosynthesis (Neale, 1987; Häder et al. 1991; Vincent and Roy, 1993; Williamson, 1995; Worrest and Häder, 1997), and its deleterious effects have been reported in a number of marine microalgae and phytoplankton communities (for a review, see Häder, 1993). The effects of ultraviolet-A (UV-A, wavelengths from 315 to $400 \mathrm{~nm}$ ) remain unclear. Even though its inhibitory effect on photosynthesis was early reported by Hirosawa and Miyachi (1983), Quesada et al. (1995) have recently suggested that UV-A could be involved in the activation of damage-repair mechanisms.

Since the response of phytoplanktonic species to UVR (mainly the UV-B component) has been shown to be speciesspecific, with selection against less tolerant species (Cullen et al., 1992; Behrenfeld et al., 1993; Neale et al., 1998), comparative studies on differential senstivity to UVR among diverse phytoplanktonic species are of interest (Neale et al., 1998). Although attention has mainly been paid to the inhibition kinetics of photosynthesis, up to date a comparison of the rate of recovery among species under the same treatment has been suggested to provide relevant data for a reliable assessment of the derived effects of exposure to UVR (Smith et al., 1992; Helbling et al., 1992; Prézelin et al., 1994; Smith and Cullen, 1995; Neale et al., 1998). According to Karentz et al. (1991), damage by UVR is dependent upon the self-shading capacity, which in turn may rely on cell morphology and the internal distribution of target molecules (García-Pichel, 1996). A comparative study on the sensitivity to photoinhibition by full solar radiation, and specifically the ultraviolet components (UV-A and/or UV-B), is reported here. Photosynthetic responses to short-term exposure were studied, as well as the subsequent time course of recovery for up to $24 \mathrm{~h}$ in dim light, using five different chlorophyll $c$-containing microalgae, but with some differences in the composition and/or organization of the photosynthetic apparatus. Algae used in this study are considered to be representative of marine phytoplankton (two diatoms, one dinoflagellate and other two flagellates from Prymnesiophyta and Cryptophyta). Comparison of algal responses was carried

\section{Introducción}

Existen evidencias de que los crecientes niveles de radiación ultravioleta (UVR) que están llegando actualmente a la superficie terrestre pueden provocar una disminución en la producción primaria oceánica, bien reduciendo la capacidad fotosintética total o bien modificando la composición de especies de las comunidades fitoplanctónicas (Häder, 1993). Específicamente, se ha visto que el componente de UVR que abarca las longitudes de onda entre 280 y $315 \mathrm{~nm}$, llamado ultravioleta-B (UV-B), puede afectar negativamente a la fotosíntesis en el medio acuático (Neale, 1987; Häder et al., 1991; Vincent y Roy, 1993; Williamson, 1995; Worrest y Häder, 1997), habiendo sido mostrados sus efectos nocivos para un buen número de microalgas marinas y comunidades fitoplanctónicas. Los efectos inhibitorios del componente denominado ultravioleta-A (UV-A, el cual comprende las longitudes de onda entre 315 y $400 \mathrm{~nm}$ ) fueron mostrados inicialmente por Hirosawa y Miyachi (1983), pero Quesada et al. (1995) han sugerido recientemente que el UV-A podría estar implicado en la activación de los mecanismos de daño-reparación.

Dado que se ha visto que la respuesta de las especies fitoplanctónicas a UVR (principalmente el componente UV-B) es específica de cada especie, con una selección negativa sobre las especies menos tolerantes (Cullen et al., 1992; Behrenfeld et al., 1993; Neale et al., 1998), resultan de interés los estudios comparativos de la sensibilidad (diferencial) de las diversas especies fitoplanctónicas a UVR (Neale et al., 1998). Si bien hasta hoy la atención se ha dirigido principalmente hacia la cinética de inhibición de la fotosíntesis, se ha sugerido que una comparación de la velocidad de recuperación entre especies bajo el mismo tratamiento proveería datos relevantes para una evaluación real de los efectos derivados de la exposición a UVR (Smith et al., 1992; Helbling et al., 1992; Prézelin et al., 1994; Smith y Cullen, 1995; Neale et al., 1998).

Ya que, según Karentz et al. (1991), el daño provocado por UVR depende de la capacidad de autosombreado, el cual a su vez puede depender de la morfología de la célula y de la distribución interna de las moléculas diana (García-Pichel, 1996), aquí se presenta un estudio comparativo de la sensibilidad a la fotoinhibición por la radiación solar completa, y más específicamente por los componentes del ultravioleta (UV-A y/o UV$\mathrm{B})$, entre cinco especies de microalgas marinas conteniendo todas ellas clorofila $c$, aunque con algunas diferencias en la composición y/u organización de su aparato fotosintético. Se estudió la respuesta de la fotosíntesis tras una corta exposición, así como durante el subsiguiente tiempo de recuperación en luz tenue hasta completar un periodo de $24 \mathrm{~h}$. Las algas usadas en este estudio pueden ser consideradas como representativas del fitoplancton marino (dos diatomeas, un dinoflagelado, y otros 
out on the basis of changes in the maximal quantum yield $\left(F_{v} / F_{m}\right)$, oxygen evolution, pigment contents and cell density.

\section{Material and methods}

\section{Experimental design}

Microalgae used in this study belong to the Marine Microalgae Culture Collection of the Instituto de Ciencias Marinas de Andalucía, CSIC (Cadiz, Spain), and were Chaetoceros sp. and Phaeodactylum tricornutum Bohlin (Bacillariophyceae), Amphidinium sp. (Pyrrhophyceae), Isochrysis aff. galbana Parke (Prymnesiophyceae) and Cryptomonas sp. (Cryptophyceae). All species were grown in natural, autoclave-sterilized seawater, enriched with $F / 2$ medium (Guillard and Ryther, 1962). Culture conditions were: $200 \mathrm{~mL}$ of culture in $250-\mathrm{mL}$ bottles with cotton top, illuminated with day-light fluorescence lamps at about $75 \mu \mathrm{mol}$ quanta $\mathrm{m}^{-2} \mathrm{~s}^{-1}$ and at $20^{\circ} \mathrm{C}$. In order to adapt algae to the growth conditions before experiments were carried out, they were grown during 3 weeks with weekly renewal of medium. Likewise, to avoid nutrient limitation during exposure, F/2 medium was added to the cultures $24 \mathrm{~h}$ before exposure.

Aliquots of $35 \mathrm{~mL}$ (in duplicate) of every algal suspension were exposed for 20 minutes in open Petri dishes, placed in a water-bath, to either photosynthetic active radiation (PAR, Ptreatment), to PAR+UV-A (PA-treatment), or to full solar radiation (PAR+UV-A+UV-B, PAB-treatment). Each ultraviolet component of the solar radiation was selectively removed in order to obtain the desired treatment by using appropiate cutoff filters (Folex 320 and Ultraphan 395) (fig. 1). Before exposure, cell suspensions were thoroughly agitated and kept in the open Petri dishes for 30-45 $\mathrm{min}$ in the culture room to facilitate gas exchange. Following exposure, algal suspensions were allowed to recover in dim light $\left(5-10 \mu \mathrm{mol}\right.$ quanta $\left.\mathrm{m}^{-2} \mathrm{~s}^{-1}\right)$ from daylight fluorescent lamps for $24 \mathrm{~h}$ at $20^{\circ} \mathrm{C}$. Even though ice was added when necessary to lower the temperature of the water-bath, it rose temporarily during exposure up to $23.2^{\circ} \mathrm{C}$, but never for more than $3 \mathrm{~min}$. Petri dishes considered as controls, with the same volume of cell suspension of each alga were kept in the recovery conditions during the experimental period. Three independent experiments were performed in three different days with similar irradiance conditions, as indicated by those available from the Cadiz station readings of the ELDONET network (see below). Cells were counted in an improved Neubauer haematocytometer.

\section{Irradiance}

The irradiance values (PAR, UV-A and UV-B) were measured with an ELDONET instrument from the Cadiz station of the ELDONET Network (Internet Home page of the ELDONET Network is http://power.ib.pi.cnr.it:80/eldonet/). The ELDONET instrument (Real Time Computer, Erlangen, Germany) was placed in a tank with water, with the collecting dos flagelados pertenecientes a las Prymnesiophyta y Cryptophyta). La comparación se llevó a cabo en base al rendimiento cuántico máximo $\left(F_{v} / F_{m}\right)$, la evolución del oxígeno fotosintético, el contenido de pigmentos y la densidad de las células.

\section{Material y métodos}

\section{Diseño experimental}

Las microalgas usadas en este estudio pertenecen a la Colección de Cultivos de Microalgas Marinas del Instituto de Ciencias Marinas de Andalucía, CSIC (Cádiz, España), y fueron Chaetoceros sp. y Phaeodactylum tricornutum Bohlin (Bacillariophyceae), Amphidinium sp. (Pyrrhophyceae), Isochrysis aff. galbana Parke (Prymnesiophyceae) y Cryptomonas sp. (Cryptophyceae). Todas las especies fueron cultivadas en agua de mar natural filtrada, esterilizada en autoclave y enriquecida con medio F/2 (Guillard y Ryther, 1962). Las condiciones de cultivo fueron: $200 \mathrm{~mL}$ de cultivo en frascos de $250 \mathrm{~mL}$ con tapón de algodón graso, iluminados con lámparas fluorescentes "day-light" a aproximadamente $75 \mu$ mol quanta $\mathrm{m}^{-2} \mathrm{~s}^{-1} \mathrm{y}$ a $20^{\circ} \mathrm{C}$. Con el fin de adaptar las algas a las condiciones de crecimiento antes de llevar a cabo los experimentos, éstas fueron previamente desarrolladas durante 3 semanas con renovación semanal del medio de cultivo. Asimismo, para evitar la limitación de nutrientes durante la exposición, se añadió medio $\mathrm{F} / 2$ a los cultivos $24 \mathrm{~h}$ antes de la exposición.

Se expusieron alícuotas de $35 \mathrm{~mL}$ (en duplicado) de cada suspensión de microalgas durante $20 \mathrm{~min}$ a la radiación fotosintéticamente activa (PAR, tratamiento-P), a PAR+UV-A (tratamiento PA), o a la radiación solar completa (PAR + UV-A + UV-B, tratamiento PAB), en cajas de Petri abiertas y colocadas sobre la superficie en un baño de agua. Con el fin de obtener el tratamiento deseado, cada componente ultravioleta de la radiación solar fue selectivamente suprimido por medio de apropiados filtros de corte (Folex 320 y Ultraphan 395) (fig. 1). Antes de la exposición, las suspensiones celulares fueron cuidadosamente agitadas y mantenidas en las cajas de Petri abiertas durante 30-45 min en la cámara de cultivos para facilitar el intercambio gaseoso. Tras la exposición, se facilitó la recuperación de las suspensiones de microalgas en luz tenue (5-10 $\mu$ mol quanta $\mathrm{m}^{-2} \mathrm{~s}^{-1}$ ) proveniente de lámparas fluorescentes "day-light" durante $24 \mathrm{~h}$ a $20^{\circ} \mathrm{C}$. Aún cuando se añadió hielo al baño de agua para bajar la temperatura siempre que fue necesario, esta subió temporalmente hasta $23.2^{\circ} \mathrm{C}$, aunque nunca por periodos de tiempo superiores a $3 \mathrm{~min}$. Como controles se utilizaron los mismos volúmenes de suspensión celular que para la exposición, colocados en cajas de Petri semiabiertas y mantenidos en las condiciones de recuperación. Se llevaron a cabo tres experimentos independientes en tres días diferentes con condiciones de irradiancia similares según las medidas disponibles de la red ELDONET en la estación de 


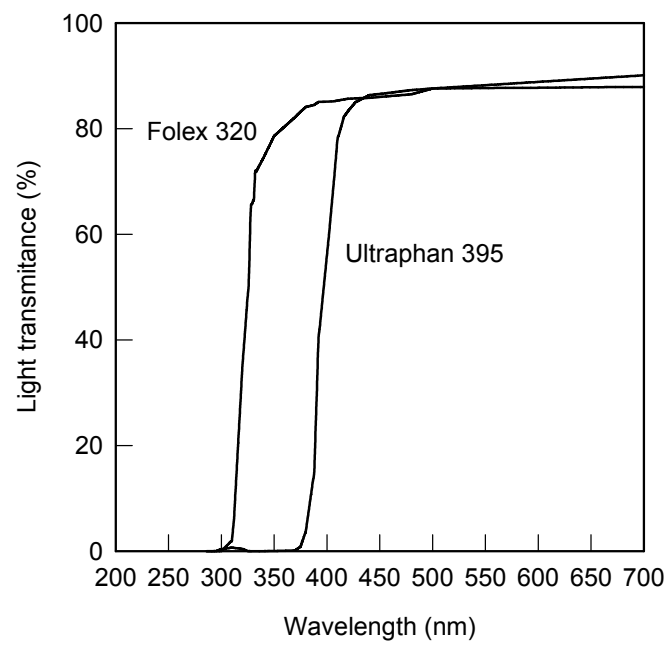

Figure 1. Percent of light transmission between 200 and $700 \mathrm{~nm}$ for cut-off filters Folex 395 and Ultraphan 320 used in experiments.

Figura 1. Porcentaje de transmisión de luz entre 200 y $700 \mathrm{~nm}$ para los filtros de corte Folex 395 y Ultraphan 320 usados en los experimentos.

window at about $1 \mathrm{~cm}$ below the water surface. The spectral bands measured by the instrument are: PAR (400-700 nm), UV-A (315-400 nm) and UV-B (280-315 nm), with high resolutions of $<0.1 \mathrm{~W} \cdot \mathrm{m}^{-2}$ for PAR, $<0.01 \mathrm{~W} \cdot \mathrm{m}^{-2}$ for UV-A and $0.0005 \mathrm{~W} \cdot \mathrm{m}^{-2}$ for UV-B (Häder, D.P. and Lebert, M.; ELDONET and WINDOSE 2000 Manual). Data were measured and integrated over 1-min intervals.

\section{Chlorophyll fluorescence measurements}

Minimal fluorescence $\left(F_{0}\right)$ and maximal fluorescence $\left(F_{\mathrm{m}}\right)$ of dark-adapted samples were measured with a pulsemodulated fluorometer (model FMS1, Hansatech Instruments Ltd., King's Lynn, UK). Samples of each alga were taken before and immediately after exposure, as well as at different time intervals during recovery; they were then kept in darkness for $10 \mathrm{~min}$ and, in order to ensure that the primary quinone acceptor of PSII (photosystem II) and the plastoquinone pool were fully oxidized (Owens, 1986), 5 to 6 pulses of low intensity far-red light $(735 \mathrm{~nm})$ were applied prior to the chlorophyll fluorescence measurements were conducted. Saturating pulse intensity and amplitude were checked to give the maximum value of $F_{m}$ in each alga. The ratio of variable to maximal fluorescence $\left(F_{v} / F_{m}\right.$, where $\left.F_{v}=F_{m}-F_{0}\right)$, the so called maximum quantum yield of photosynthesis, was used as indicator of photoinhibition (Schreiber et al. 1986; Schreiber et al., 1994).

Photosynthetic oxygen production

The oxygen evolution was measured with a Clark-type electrode (Hansatech Instruments, Kyng's Lynn, UK) at $20^{\circ} \mathrm{C}$. A 1-mL sample was placed in a cuvette for liquid-phase measurements (DW2, Hansatech Instruments, Kyng's Lynn, UK), where the electrode was inserted and which was equipped
Cádiz (ver a continuación). El recuento celular se hizo en un hematocitómetro Neubauer mejorado.

Medidas de irradiancia

Los valores de irradiancia fueron medidos con un instrumento ELDONET disponible en la estación de Cádiz de la red ELDONET (la página de internet de la red ELDONET es http://power.ib.pi.cnr.it:80/eldonet/). El instrumento ELDONET (Real Time Computer, Erlangen, Alemania) fue situado en un tanque con agua, con la ventana colectora aproximadamente $1 \mathrm{~cm}$ por debajo de la superficie del agua. Las bandas espectrales medidas por el instrumento son: PAR (400-700 $\mathrm{nm})$, UV-A (315-400 nm) y UV-B (280-315 nm), con altas resoluciones de $<0.1 \mathrm{~W} \cdot \mathrm{m}^{-2}$ para $\mathrm{PAR},<0.01 \mathrm{~W} \cdot \mathrm{m}^{-2}$ para $\mathrm{UV}$ A y $0.0005 \mathrm{~W} \cdot \mathrm{m}^{-2}$ para UV-B (Häder, D.-P. y Lebert, M.; ELDONET y WINDOSE 2000 Manual). Los datos fueron medidos e integrados a intervalos de $1 \mathrm{~min}$.

Medidas de la fluorescencia de la clorofila

Se midieron las fluorescencias mínima $\left(\mathrm{F}_{0}\right)$ y máxima $\left(\mathrm{F}_{\mathrm{m}}\right)$ de muestras adaptadas a la oscuridad con un fluorímetro de pulso modulado (modelo FMS1, Hansatech Instruments Ltd., King's Lynn, UK). Se tomaron muestras de cada alga antes e inmediatamente después de la exposición, así como a diferentes intervalos de tiempo durante el periodo de recuperación; antes de realizar las medidas de fluorescencia de la clorofila, las muestras se mantuvieron en la oscuridad durante $10 \mathrm{~min}$ y, para asegurar la completa oxidación de la quinona aceptora primaria de PSII (fotosistema II) y del conjunto de plastoquinonas (Owens, 1986), se aplicaron de 5 a 6 pulsos de luz en el rojo lejano $(735 \mathrm{~nm})$. En cada alga se comprobaron la intensidad del pulso saturante y la amplitud que daban el máximo valor de $F_{m}$. Como indicador de fotoinhibición se usó el cociente entre fluorescencia variable y máxima fluorescencia $\left(F_{v} / F_{m}\right.$, siendo $F_{v}=F_{m}-F_{0}$ ), el cual es conocido como rendimiento cuántico máximo de la fotosíntesis (Schreiber et al., 1986; Schreiber et al., 1994).

\section{Producción fotosintética de oxígeno}

La evolución del oxígeno fue medida con un electrodo tipo Clark (Hansatech Instruments, Kyng's Lynn, UK) a $20^{\circ} \mathrm{C}$. Se colocó una muestra de $1 \mathrm{~mL}$ en una cubeta para medidas en fase líquida (DW2, Hansatech Instruments, Kyng's Lynn, UK), en la cual se introdujo el electrodo, equipada con una camisa exterior de termostatización. Para la iluminación se utilizó una lámpara tipo Björkman. La irradiancia en el interior de la cubeta fue medida con un sensor PAR Quantitherm (Hansatech Instruments, Kyng's Lynn, U.K.), dando un valor de 1386 $\pm 25 \mu \mathrm{mol}$ quanta $\mathrm{m}^{-2} \mathrm{~s}^{-1}$. La evolución del oxígeno se midió durante un periodo de 3 a 5 minutos, y se calculó como nmol $\mathrm{O}_{2} \mathrm{~h}^{-1}\left(10^{6} \text { celulas }\right)^{-1}$ y como $\mathrm{mmol} \mathrm{O}_{2} \mathrm{~h}^{-1}(\mathrm{mg} \text { clorofila } a)^{-1}$. 
with an outer jacket for thermostat-controlled watertemperature. Light was provided by a Bjorkman-type lamp. Irradiance inside the cuvette was measured with a PAR sensor (Quantitherm, Hansatech Instruments, Kyng's Lynn, $\mathrm{UK}$ ), and was $1386 \pm 25 \mu \mathrm{mol}$ quanta $\mathrm{m}^{-2} \mathrm{~s}^{-1}$. Oxygen evolution was determined over a 3- or 5-min measuring period, and calculated as nmol $\mathrm{O}_{2} \mathrm{~h}^{-1}\left(10^{6} \text { cells }\right)^{-1}$ and $\mathrm{mmol} \mathrm{O}^{2} \mathrm{~h}^{-1}(\mathrm{mg} \mathrm{Chl} a)^{-1}$.

\section{Pigments}

Pigment content was determined spectrophotometrically in methanol extracts from 2-mL samples of the algal suspensions. Cells were harvested by centrifugation at $3000 \mathrm{rpm}$ during 15 min at $4^{\circ} \mathrm{C}$. After the supernatant was discarded, the pellet was resuspended in $1.5 \mathrm{~mL}$ methanol (HPLC grade), shaken vigorously and kept at $4^{\circ} \mathrm{C}$ overnight. The liquid phase was then collected by centrifugation, and absorbance at appropiate wavelengths immediately measured. Different pigment contents in the methanolic extract were calculated according to the following equations: Chlorophyll $a\left(\mu \mathrm{g} \mathrm{mL} \mathrm{mL}^{-1}\right)=13.9 \mathrm{~A}_{665}$ (Talling and Driver, 1963); Chlorophyll $c\left(\mu \mathrm{g} \mathrm{mL}^{-1}\right)=67.3 \mathrm{~A}_{635}$ - 14.1 A $\mathrm{A}_{668}$ (Jeffrey and Haxo, 1968); and Carotenes + Xanthophylls $\left(\mu \mathrm{g} \mathrm{mL}^{-1}\right)=4 \mathrm{~A}_{480}$ (Strickland and Parsons, 1968).

\section{Data analysis and statistics}

The $F_{v} / F_{m}$ and oxygen evolution (OE) values after exposure and at a given time during recovery, $\left(F_{v} / F_{m}\right)_{t}$, were fitted to an exponential sigmoidal function of the type:

$$
f(t)=p-q \exp (-s t)
$$

where $f(t)=\left(F_{v} / F_{m}\right)_{t}$ or $(\mathrm{OE})_{t} ; p, q$ and $s$ are specific constants to be determined for every alga and treatment, and $t$ is time. This equation was chosen because it gave a good fit according to the correlation coefficient $\left(r^{2}\right)$, besides matching the conditions of having an intercept $(p-q)$ not necessarily equal to 0 and a finite asymptotic value $(p)$. The time constant $s\left(\mathrm{~h}^{-1}\right)$ can be referred to the rapidity with which $f(t)$ attains the asymptote, and thus considered as a measure of the recovery rate. All fits were carried out by means of the non-linear regression application of the StatGraphics 5.0 software, which uses the Marquardt-Levenberg algorithm.

Complete statistical analysis was carried out by analysis of variance (one-way or two-way ANOVA) with treatment and time, or algae and time as factors. Data with heterogeneous variances were transformed by $\log ((x+i) 100)$, with $i=1,0.5$ or 0.1 . A post hoc Newman-Keuls' test was used, and $P$-values of less than 0.05 were accepted for significant differences.
Pigmentos

El contenido pigmentario se determinó espectrofotométricamente en extractos de metanol a partir de muestras de $2 \mathrm{~mL}$ de las suspensiones celulares. Las células se recogieron por centrifugación a $3000 \mathrm{rpm}$ durante $15 \mathrm{~min}$ a $4^{\circ} \mathrm{C}$. Tras desechar el sobrenadante, el residuo sólido fue resuspendido en $1.5 \mathrm{~mL}$ de metanol (calidad HPLC), agitado vigorosamente y mantenido a $4^{\circ} \mathrm{C}$ hasta el día siguiente. La fase líquida se recogió tras centrifugar la suspensión y se midió inmediatamente su absorbancia a las longitudes de onda apropiadas. Los diferentes contenidos pigmentarios en el extracto metanólico fueron calculados según las ecuaciones siguientes: clorofila $a\left(\mu \mathrm{g} \mathrm{mL}^{-1}\right)$ $=13.9 \mathrm{~A}_{665}$ (Talling y Driver, 1963); clorofila $c\left(\mu \mathrm{g} \mathrm{mL}{ }^{-1}\right)=$ $67.3 \mathrm{~A}_{635}-14.1 \mathrm{~A}_{668}$ (Jeffrey y Haxo, 1968); y Carotenos + Xantofilas $\left(\mu \mathrm{g} \mathrm{mL}^{-1}\right)=4 \mathrm{~A}_{480}$ (Strickland y Parsons, 1968).

Análisis de los datos y estadística

Los valores de $F_{v} / F_{m}$ y de la evolución del oxígeno (OE), tras la exposición y a un tiempo dado durante la recuperación, $\left(F_{v} / F_{m}\right)_{t}$, fueron ajustados a una función exponencial sigmoide del tipo:

$$
f(t)=p-q \exp (-s t)
$$

donde $f(t)=\left(F_{v} / F_{m}\right)_{t}$ ó $(\mathrm{OE})_{t} ; p, q$ y $s$ son constantes específicas a determinar a partir de la ecuación para cada alga y tratamiento, y $t$ es el tiempo. Se escogió esta ecuación porque fue la que dió el mejor ajuste de acuerdo con el coeficiente de correlación $\left(r^{2}\right)$, además de cumplir las condiciones de tener una ordenada al origen no necesariamente igual a 0 y un valor finito de la asíntota $(p)$. La constante de tiempo $s\left(\mathrm{~h}^{-1}\right)$ puede relacionarse con la rapidez con que $f(t)$ alcanza la asíntota $\mathrm{y}$, por tanto, puede ser considerada una medida de la velocidad de recuperación. Todos los ajustes se llevaron a cabo mediante la aplicación de una regresión no lineal contenida en el paquete informático StatGraphics 5.0, la cual se basa en el algoritmo de Marquardt-Levenberg.

Se llevó a cabo un completo análisis estadístico por análisis de varianza (ANOVA de una o dos vías) con el tratamiento y el tiempo, o algas y el tiempo como factores. Los datos con varianzas heterogéneas fueron transformados a $\log ((x+i) 100)$, con $i=1,0.5$ ó 0.1 . Como test a posteriori se usó el de Newman-Keuls, y las diferencias significativas se aceptaron para valores de $P$ menores de 0.05 .

\section{Resultados}

Irradiancia

Los rangos de irradiancias (sin compensación biológica) durante los experimentos fueron 1.11-1.53 $( \pm 0.13) \mathrm{W} \mathrm{m}^{-2}$ para UV-B, 49.35-57.35 ( \pm 2.06$) \mathrm{W} \mathrm{m}^{-2}$ para UV-A, y 374.03- 


\section{Results}

Irradiance

The irradiance ranges (biologically unweighted) over the experimental days were 1.11-1.53 $( \pm 0.13) \mathrm{W} \mathrm{m}^{-2}$ for UV-B, 49.35-57.35 $( \pm 2.06) \mathrm{W} \mathrm{m}^{-2}$ for UV-A, and 374.03-424.77 $( \pm 18.53) \mathrm{W} \mathrm{m}^{-2}$ for PAR; values into brackets are the maximal variation over the experimental period. Irradiance $\left(\mathrm{W} \mathrm{m}^{-2}\right)$ was reduced by the cut-off filters $(320 \mathrm{~nm}$ and $395 \mathrm{~nm}$, respectively) to the following values: 370.25 and 365.14 (PAR), 41.69 and 4.73 (UV-A), and 0.20 and $<0.01$ (UV-B).

\section{Chlorophyll fluorescence}

The rise in $F_{v} / F_{m}$ of the control at the end of the experimental period as compared with the initial values (table 1) indicated that no additional detrimental effects can be attributed to carbon or nutrient limitations. Less photoinhibition after the 20 min period of exposure, as measured by the decrease in the $F_{v} /$ $F_{m}$ value in relation to the initial, resulted in all the algae when UV-A and/or UV-B were screened out. However, only Amphidinium sp. and Chaetoceros sp. exhibited significant differences of the $F_{v} / F_{m}$ value after exposure between the PA- and PAB-treatments. Maximum photoinhibition for the PAB treatment was undergone by $P$. tricornutum, Amphidinium sp. and $I$. galbana (about 95\%). Screening out of the UV-B component (PA-treatment) did not reduce significantly the extent of inhibition in these algae. Likewise, the extent of inhibition did not vary significantly in $P$. tricornutum when UV-A was else removed (P-treatment) (table 1$)$.

Increasing values of $F_{v} / F_{m}$ were observed in all the algae with recovery time (fig. 2). The lines in figure 2 were obtained by fitting the $F_{v} / F_{m}$ recovery data (normalized to initial data) to a sigmoid exponential function $f(t)=p-q \exp (-s t)$, and values of the time constants, $s\left(\mathrm{~h}^{-1}\right)$, are shown in table 2 for each alga and treatment. The highest value of $s$ was shown by $P$. tricornutum after inhibition by only PAR. Significant differences between the time constants of the three treatments were only shown by $I$. galbana $(F=50.56, P<0.001)$ and $P$. tricornutum $(F=85.26, P<0.001)$, with increasing values as shorter wavelengths were removed. No significant differences $(F=2.41, P>0.05)$ between treatments were shown by Amphidinium sp. Differences in time constants were only shown for the P-treatment (with the highest time constant) with regard to the PA- and PAB-treatments in Chaetoceros sp. $(F=6.88, P<0.05)$ and Cryptomonas sp. $(F=24.39$, $P<0.001)$. The algae with statistically comparable time constants, that is, forming an homogeneous group, are indicated in table 2 by the same superscript letter. The composition of the homogeneous groups varied from one treatment to another. On the one hand, only I. galbana and Cryptomonas sp. fell within the same group in the PA- and P-treatments and, on the other hand did Cryptomonas sp. and Amphidinium sp. in treatments PAB and PA. The diatoms showed a similar to each other response solely in the PA-treatment.
$424.77( \pm 18.53) \mathrm{W} \mathrm{m}^{-2}$ para PAR; los valores entre paréntesis indican la variación máxima durante el periodo experimental. Sin embargo, los filtros de corte selectivo (320 nm y $395 \mathrm{~nm}$ ) redujeron dichos valores de irradiancia $\left(\mathrm{W} \mathrm{m}^{-2}\right)$ a los siguientes: 370.25 y 365.14 (PAR), 41.69 y 4.73 (UV-A), y 0.20 y $<0.01$ (UV-B), para los tratamientos PAB y PA, respectivamente.

\section{Fluorescencia de la clorofila}

El aumento de $F_{v} / F_{m}$ de los controles al final del periodo experimental, en relación al valor inicial (tabla 1), es indicativo de que no hubo efectos nocivos adicionales que pudieran ser atribuidos a la limitación de carbono o de nutrientes. La eliminación de UV-A y/o UV-B resultó en una menor inhibición en todas las algas, siendo medida ésta por el descenso en el valor de $F_{v} / F_{m}$ tras el periodo de exposición de 20 min en relación al valor inicial. Sin embargo, solo Amphidinium sp. y Chaetoceros sp. exhibieron diferencias significativas, tras la exposición, en el valor de $F_{v} / F_{m}$ entre los tratamientos PA y PAB. Phaeodactylum tricornutum, Amphidinium sp. e $I$. galbana fueron las algas que experimentaron la máxima inhibición (aproximadamente 95\%) en el tratamiento PAB. La eliminación del componente UV-B (tratamiento PA) no redujo significativamente el alcance de la inhibición en estas algas. Asimismo, el grado de inhibición no varió significativamente en $P$. tricornutum cuando el componente UV-A fue también apantallado (tratamiento P) (tabla 1).

En todas las algas se observaron valores crecientes de $F_{v} / F_{m}$ con el tiempo de recuperación (fig. 2). Las líneas en la figura 2 fueron trazadas según la ecuación resultante del ajuste de los datos de $F_{v} / F_{m}$ durante la recuperación (normalizados en relación a los iniciales) a una función exponencial sigmoidea $f(t)=p-q \exp (-\mathrm{st})$. En la tabla 2 se presentan los valores de las constantes de tiempo $s\left(\mathrm{~h}^{-1}\right)$ para cada alga y tratamiento. Phaedactylum tricornutum mostró el valor más alto de $s$ tras la inhibición por PAR solamente. Únicamente I. galbana $(F=50.56, P<0.001)$ y $P$. tricornutum $(F=85.26, P<0.001)$ mostraron diferencias significativas en las constantes de tiempo entre los tres tratamientos, con valores crecientes a medida que las longitudes de onda más cortas fueron suprimidas. Las constantes de tiempo de Amphidinium sp. no mostraron diferencias significativas $(F=2.41, P>0.05)$ en ningún tratamiento. Solo se observaron diferencias en las constantes de tiempo entre el tratamiento $\mathrm{P}$ (con la constante más alta) y los tratamientos PA y PAB en Chaetoceros sp. $(F=6.88$, $P<0.05)$ y Cryptomonas sp. $(F=24.39, P<0.001)$. Las algas con constantes de tiempo estadísticamente comparables, es decir, formando un grupo homogéneo, dentro de cada tratamiento se indican en la tabla 2 por el mismo superíndice. La composición de los grupos cambió de un tratamiento a otro, y solamente I. galbana y Cryptomonas sp. mantuvieron la homogeneidad en los tratamientos PA y P, por un lado, y Cryptomonas sp. y Amphidinium sp. en los tratamientos PAB y PA, por otro lado. Las dos diatomeas solo mostraron una respuesta similar en el tratamiento PA. 


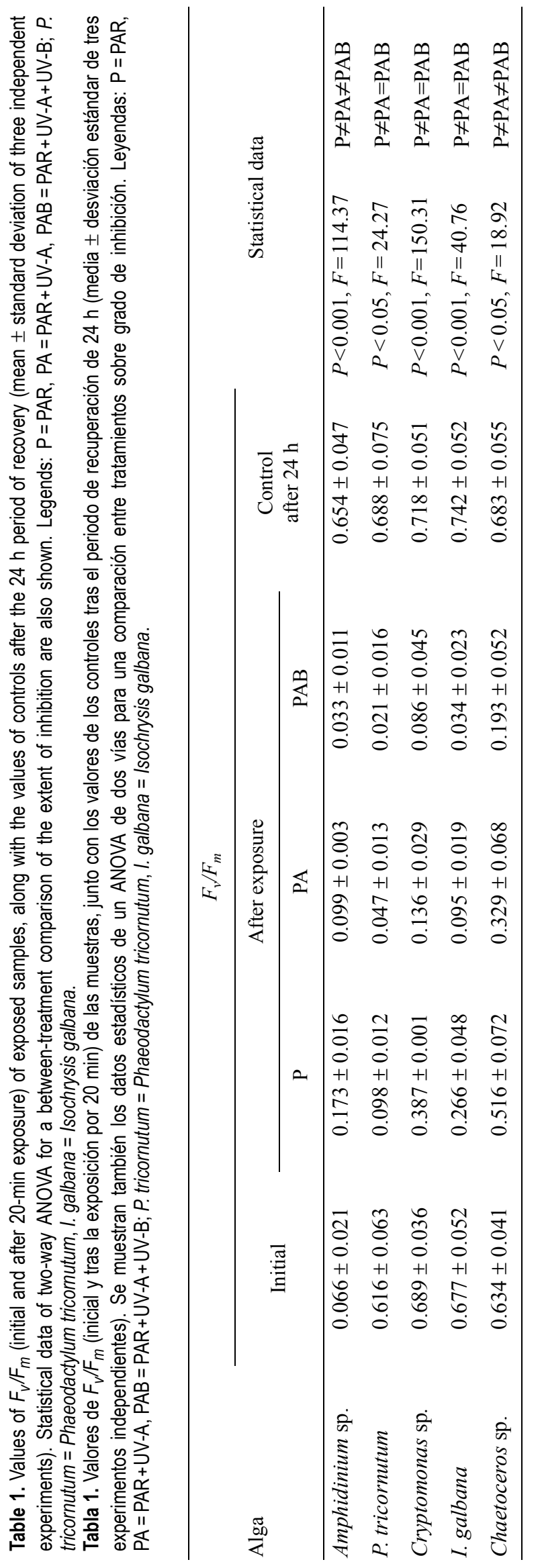

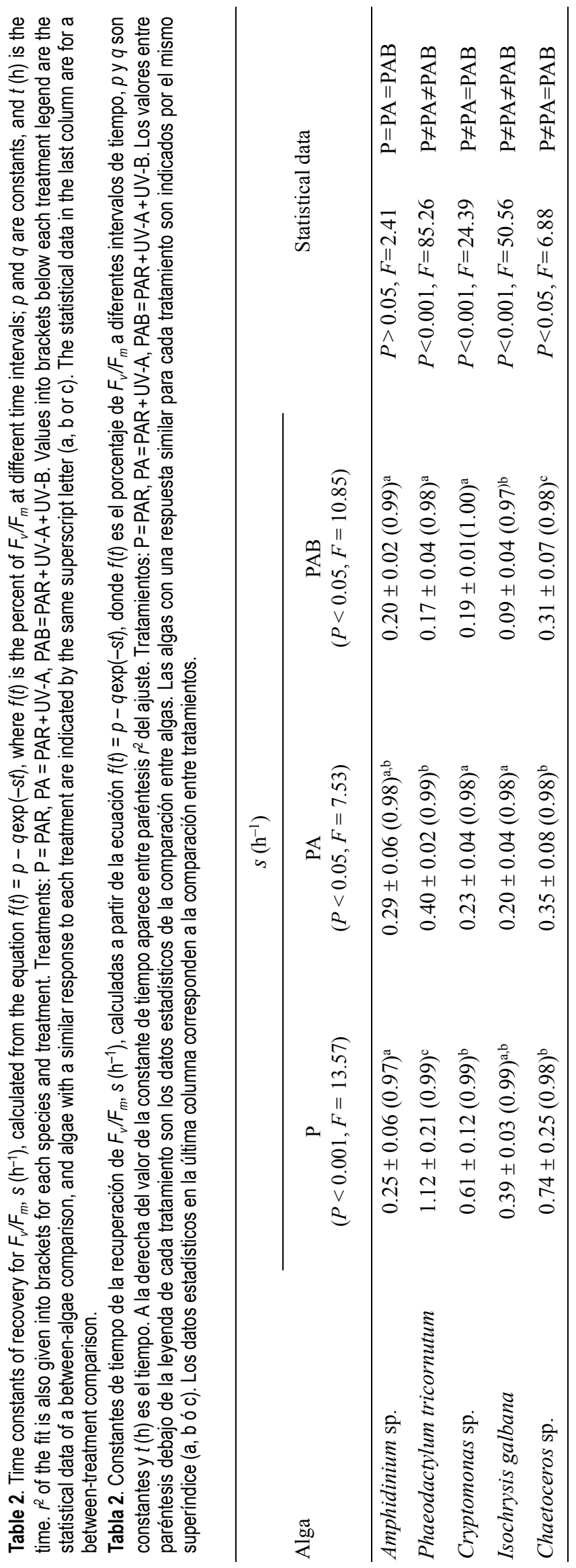




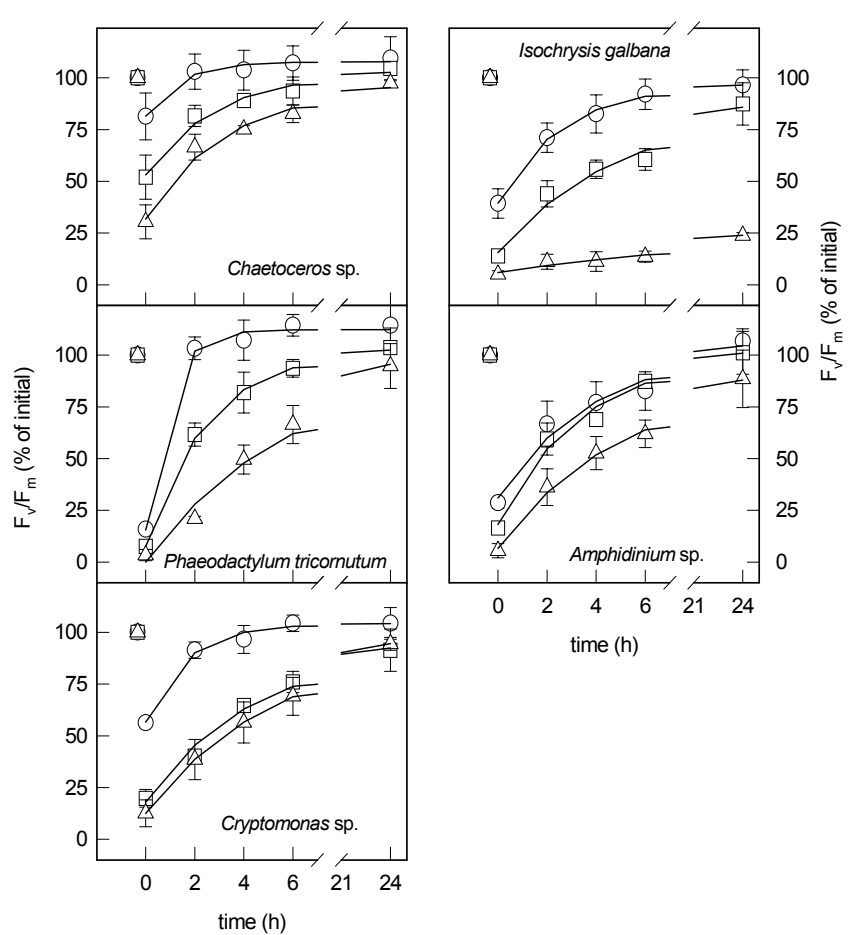

In relation to controls there was loss of recovery in $F_{v} / F_{m}$ of exposed cells after $24 \mathrm{~h}$ in dim light only in Cryptomonas sp. for the PAB-treatment $(F=8.752, P<0.05)$, and in $I$. galbana for the PA- and PAB-treatments $(F=61.625$, $P<0.001)$.

\section{Oxygen evolution}

Initial and after exposure values of net oxygen evolution are shown in table 3. Oxygen evolution fell to 0 or even to negative values after the $20 \mathrm{~min}$ period of exposure in all the algae in treatments involving UV-A and UV-B, but the decrease in the only PAR-treatment was less pronounced. After exposed cells were transferred to recovery conditions, oxygen evolution rose gradually. The time constants resulting from the fit of the values during recovery to a sigmoid exponential function (see Materials and methods), $s_{\mathrm{OE}}(t)\left(\mathrm{h}^{-1}\right)$, are shown in table 3. Since only three values of oxygen evolution were used for each treatment (after exposure and after 4 and $24 \mathrm{~h}$ of recovery), statistical parameters are not provided due to their poor significance. The highest values of $s_{\mathrm{OE}}(t)$ were shown by Amphidinium sp. and P. tricornutum for the PA- and PAB-treatments, while the lowest was shown by I. galbana.

The data pooled of oxygen evolution during recovery showed a linear correlation with the corresponding values of $F_{v} / F_{m}$ (both as percent of the initial ones), with a positive slope of $1.74\left(r^{2}=0.62, n=36\right)$ if $\left(F_{v} / F_{m}\right)_{t} /\left(F_{v} / F_{m}\right)_{i}$ values $>100$ were excluded. A linear correlation with slope $>1$ was also obtained for data from each alga, exception for $P$. tricornutum (slope $<1$ ). However, a correlation between the time constants could not be found.
Figure 2. Values of $F_{v} / F_{m}$ expressed as the percentage of the initial value after 20 min of exposure ( $t=0$ in the figure) to PAR (circle), PAR+UV-A (square) and PAR+UV-A+UV-B (triangle), and subsequent recovery in dim light for up to $24 \mathrm{~h}$, for the five algae studied. Lines were drawn from the fit of recovery data to a sigmoid exponential function $f(t)=p-q \exp (-s t)$, where $f(t)$ is $F_{v} / F_{m}$ at a given time (in percent of the initial value); $p, q$ and $s$ $\left(\mathrm{h}^{-1}\right)$ are constants determined from the fit and $t(h)$ is the time.

Figura 2. Valores de $F_{v} / F_{m}$ expresados como porcentaje del valor inicial tras 20 min de exposición ( $t=0$ en la figura) a PAR (círculos), PAR+UV-A (cuadrado) y PAR+UV-A+UV-B (triángulo), y la subsiguiente recuperación en luz tenue durante $24 \mathrm{~h}$, para las cinco algas estudiadas. Las líneas fueron trazadas a partir del ajuste de datos de recuperación a una función exponencial sigmoidea $f(t)=p-q \exp (-s t)$, donde $f(t)$ es $F_{v} / F_{m}$ a un tiempo dado (como porcentaje del inicial); $p, q$ y $s\left(h^{-1}\right)$ son constantes determinadas a partir del ajuste y $t(h)$ es el tiempo.

En relación a los controles, solamente en Cryptomonas sp. para el tratamiento PAB $(F=8.752, P<0.05)$ y en $I$. galbana para los tratamientos PA y $\mathrm{PAB}(F=61.625, P<0.001)$, hubo pérdida de recuperación del valor de $F_{v} / F_{m}$ de las células expuestas tras $24 \mathrm{~h}$ en luz tenue.

Evolución del oxígeno

Los valores de evolución neta del oxígeno, iniciales e inmediatamente posteriores a la exposición, se muestran en la tabla 3. La evolución del oxígeno cayó a 0 ó incluso a valores negativos tras el periodo de 20 min de exposición en todas las algas en el tratamiento PAB y en algunas en el tratamiento PA, pero el descenso en el tratamiento con solo PAR fue menos pronunciado. Después de que las células expuestas fueron transferidas a las condiciones de recuperación, la evolución del oxígeno se elevó gradualmente. Las constantes de tiempo, $s_{\mathrm{OE}}(t)\left(\mathrm{h}^{-1}\right)$, resultantes del ajuste de los valores durante la recuperación a una función exponencial sigmoidea (ver Material y métodos) se muestran en la tabla 3. Dado que solamente se usaron tres valores de evolución del oxígeno para cada tratamiento (tras la exposición y tras 4 y $24 \mathrm{~h}$ de recuperación), no se muestran los parámetros estadísticos debido a su escasa significancia. Amphidinium sp. y P. tricornutum presentaron los valores más altos de $s_{\mathrm{OE}}(t)$ en los tratamientos PA y $\mathrm{PAB}$, mientras que el más bajo fue el obtenido para I. galbana.

El conjunto de los datos de evolución de oxígeno durante la recuperación mostró una correlación lineal con los correspondientes valores de $F_{v} / F_{m}$ (ambos como porcentaje de los valores iniciales), con una pendiente positiva de $1.74\left(r^{2}=0.62\right.$, $n=36)$ cuando los valores de $\left(F_{v} / F_{m}\right)_{t} /\left(F_{v} / F_{m}\right)_{i}>100$ fueron excluidos.

\section{Densidad celular}

Durante el curso de los experimentos se observó pérdida de densidad celular tras $4 \mathrm{~h}$ de recuperación en Amphidinium sp., Cryptomonas sp. and I. galbana (fig. 3). Sin embargo, después de $24 \mathrm{~h}$ de recuperación se produjo un incremento significativo en la densidad celular de las muestras expuestas con respecto a las iniciales en P. tricornutum $(F=60.173, P<0.001)$ e $I$. 


\section{Cell density}

Losses of cell density during the course of the experiment were observed after $4 \mathrm{~h}$ of recovery in Amphidinium sp., Cryptomonas sp. and I. galbana (fig. 3). However, after $24 \mathrm{~h}$ of recovery, changes (increases) in cell density of exposed samples with regard to the initial ones were only significant for $P$. tricornutum $(F=60.173, P<0.001)$ and I. galbana $(F=6.102$, $P<0.05)$. There were no differences between treatments or in relation to controls.

\section{Pigments}

Significant changes in chlorophyll $a$ contents (in $\mu \mathrm{g}$ pigment $\left[10^{6} \text { cells }\right]^{-1}$ ) after the recovery period in relation to the initial contents were only observed in Cryptomonas sp., with less reduction in the chl $a$ content as shorter wavelengths were screened out (table 4). In contrast, the chlorophyll $c$ to chlorophyll $a$ ratio $(\operatorname{chl} c / \operatorname{chl} a)$ decreased in all the algae but in $I$. galbana (table 4). The largest decrease in the chl $c / \mathrm{chl} a$ ratio was undergone by Cryptomonas sp. under the PAB-treatment. Significant reduction in the ratio of total carotenoids to chlorophyll $a(\mathrm{Car} / \mathrm{chl} a)$ of exposed cells took place in $P$. tricornutum, Cryptomonas sp., and I. galbana.

\section{Discussion}

The relative inhibition of photosynthesis by each component of the solar spectrum after short-term exposure (20 min), as well as its further recovery in dim light, are shown here in an exclusion experiment for five marine microalgae. The experimental setup used in this study does not pretend to mimic natural (oceanic) conditions, where phytoplankton is gradually acclimated to daily changes in irradiance levels of solar radiation, including both PAR and UVR, besides other differential factors (Vincent and Roy, 1993; Smith and Cullen, 1995; Quesada et al., 1995; Worrest and Häder, 1997). However, our experimental setup is thought to be useful for assessing effects involved in variations in sensitivity among phytoplanktonic species if the following features are taken into consideration: (a) solar radiation was used and, thereby, light regime matches natural conditions; and (b) despite using cells grown in laboratory under low irradiance and, hence failing in gradual acclimation as indicated above, our results can be representative for the current situation in which the microalgae cells are advected from deeper water (shade-adapted cells) to surface waters due to mixing processes, thus showing potential differential responses of different microalgal cells to changes in environmental conditions (Beherenfeld et al., 1993; Villafañe et al., 1995).

Differential tolerance to UVR between the algae studied here is shown in relation to the extent of inhibition (this measured as the decrease in $F_{v} / F_{m}$ ) and the time course of recovery. Chaetoceros sp. was the least affected alga by both UVR and galbana $(F=6.102, P<0.05)$. No hubo diferencias entre los tratamientos, o en relación a los controles.

\section{Pigmentos}

Solamente se observaron cambios significativos en el contenido de clorofila $a$ (en $\mu$ g pigmento $\left[10^{6} \text { celulas }\right]^{-1}$ ) tras el periodo de recuperación en relación al inicial en Cryptomonas sp., con una reducción menor en el contenido de clorofila $a$ a medida que las longitudes de onda más cortas fueron eliminadas (tabla 4). En cambio, el cociente del contenido de clorofila $c$ entre el de clorofila $a(\operatorname{chl} c / \operatorname{chl} a)$ descendió en todas las algas menos en I. galbana (tabla 4). El mayor descenso en el cociente $\operatorname{chl} c / \mathrm{chl} a$ tuvo lugar en Cryptomonas sp. bajo el tratamiento PAB. Phaedactylum tricornutum, Cryptomonas sp. e I. galbana experimentaron una reducción significativa en el cociente entre los carotenoides totales y la clorofila $a$ $(\mathrm{Car} / \mathrm{chl} a)$ de las células expuestas.

\section{Discusión}

En este trabajo se estudiaron la inhibición relativa de la fotosíntesis por cada componente del espectro solar tras una breve exposición (20 min), así como la posterior recuperación en luz tenue para cinco microalgas marinas, en un experimento de exclusión selectiva de longitudes de onda. El diseño experimental usado en este estudio no pretende imitar las condiciones naturales (oceánicas), en donde la aclimatación del fitoplancton a los cambios diarios en los niveles de irradiancia de la radiación solar, incluyendo PAR y UVR, es gradual, además de la existencia de otros factores diferenciadores (Vincent y Roy, 1993; Smith y Cullen, 1995; Quesada et al., 1995; Worrest y Häder, 1997). Sin embargo, nuestros resultados pueden considerarse útiles en la valoración de los efectos implicados en las variaciones en sensibilidad entre especies fitoplanctónicas si se tienen en cuenta los siguientes datos: (a) se usó radiación solar $\mathrm{y}$, por tanto, el régimen lúminico iguala el de condiciones naturales; (b) a pesar de que se usaron células crecidas en el laboratorio con baja irradiancia y, de aquí que no se den condiciones de aclimatación gradual tal como se indicó previamente, nuestros resultados pueden ser representativos de la común situación en que las células de microalgas son proyectadas desde aguas profundas (células adaptadas a la sombra) hacia la superficie debido a los procesos de mezcla, mostrando así las diferentes potenciales respuestas de las diversas células microalgales a cambios en las condiciones ambientales (Behrenfeld et al., 1993; Villafañe et al., 1995).

Las diferencias de tolerancia a la UVR entre las algas estudiadas se muestran aquí en relación al alcance de la inhibición (medida ésta como el descenso en $F_{v} / F_{m}$ ) y el curso temporal de recuperación. Chaetoceros sp. fue la microalga menos afectada por ambos UVR y PAR. En cambio, la otra diatomea, $P$. tricornutum, se encontró entre las algas más afectadas por cualquier rango de luz solar. No obstante, esta última especie fue menos afectada que los flagelados cuando UV-B fue 


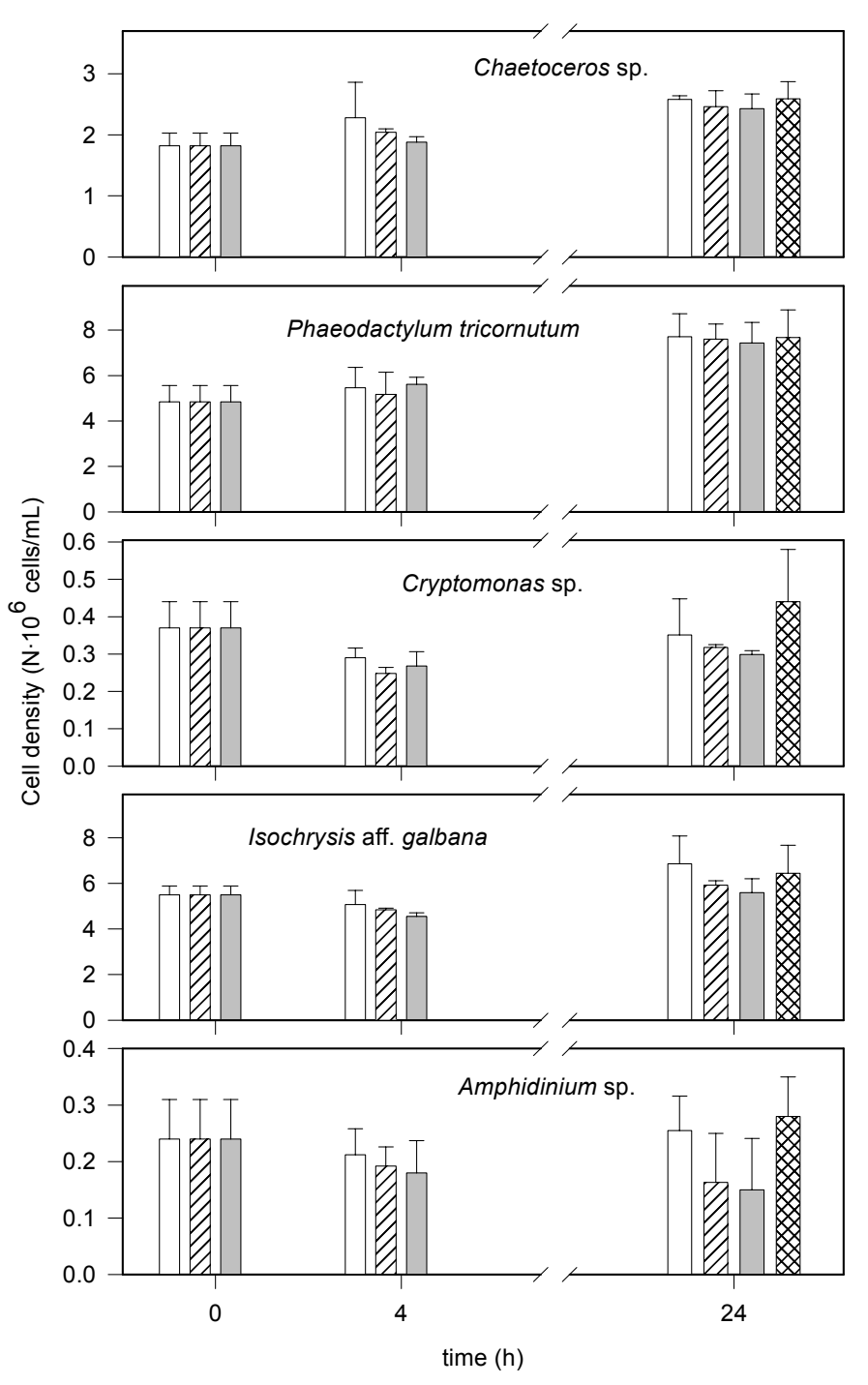

PAR. In contrast, the other diatom, P. tricornutum, fell within the most affected algae by any segment of sunlight. Nonetheless, this latter alga was less affected than flagellates when UVB was filtered out, besides showing the largest capability for recovery under PAR+UV-A conditions. Isochrisis galbana, a small flagellate, was the most sensitive alga to full sunlight, whereas the extent of inhibition under PAB in this alga was similar to the extent of inhibition in the other flagellates and $P$. tricornutum, the time constant for recovery was much lower. Results of this study are therefore in agreement with the heterogeneous response to UVR that has been found within diatoms, at least for DNA damage and cell survival (Karentz et $a l$., 1991), as well as with the fact that, in a broad sense, flagellates are more sensitive to UVR than diatoms (Helbling et al., 1994; Villafañe et al., 1995).

There was not a direct correlation between the extent of inhibition and the recovery rate (time constants), as Roos and Vincent (1998) have stated. Despite there are not significant differences in the extent of inhibition between the PA- and
Figure 3. Cell densities of the different algae suspensions at the onset of the experiment and after 4 and $24 \mathrm{~h}$ of recovery following exposure to PAR (open bars), PAR+UV-A (striped bars) and PAR+UV-A+UV-B (shaded bars). Crossed bars at $t=24 \mathrm{~h}$ represent cell densities of controls at the end of the experimental period. Note the different scales of the $Y$-axes.

Figura 3. Densidades celulares de las distintas suspensiones de microalgas al inicio del experimento y tras 4 y $24 \mathrm{~h}$ de recuperación tras la exposición a PAR (barra blancas), PAR+UV-A (barras rayadas) y $P A R+U V-A+U V-B$ (barras oscuras). Las barras con líneas cruzadas en $t=$ $24 \mathrm{~h}$ representan las densidades celulares de los controles al final del periodo experimental. Nótense las diferentes escalas de los ejes $Y$.

eliminado, mostrando además la mayor capacidad de recuperación bajo las condiciones de PAR+UV-A. Por otro lado, I. galbana, un pequeño flagelado, fue el alga más sensible a la luz solar completa; así, mientras que el alcance de la inhibición bajo PAB en este alga fue similar al alcance de la inhibición en los otros flagelados y en P. tricornutum, con una constante de tiempo para la recuperación mucho más baja. Los resultados de este estudio están por tanto de acuerdo con la respuesta heterogénea a UVR que se ha encontrado entre las diatomeas, al menos para daño al ADN y supervivencia celular (Karentz et al. 1991), así como con el hecho de que, en un sentido amplio, los flagelados son más sensibles a UVR que las diatomeas (Helbling et al., 1994; Villafañe et al., 1995).

No hubo una correlación directa del grado de inhibición con la velocidad de recuperación (constantes de tiempo), tal como Roos y Vincent (1998) han manifestado. A pesar de no haber diferencias significativas en el grado de inhibición entre los tratamientos PA y PAB en I. galbana y P. tricornutum, las constantes temporales de recuperación aumentaron significativamente cuando UV-B fue suprimido. Se asume por tanto que un factor adicional contribuyó a la inhibición en el tratamiento $\mathrm{PAB}$, en comparación al tratamiento PA en estas algas. En la fotoinhibición de estas algas tras su exposición a UV-A+UV-B pudieron estar implicados daños en el fotosistema II (PSII) (Strid et al. 1994) y en la Rubisco (ribulosa-1,5-bifosfato-carboxilasa/oxigenasa) (Nogués y Baker 1995) pero, cuando se eliminó UV-B, sólo hubo daño en PSII. El daño a las enzimas implicadas en las reacciones oscuras de la fotosíntesis en $P$. tricornutum también es evidenciado por el hecho de que la pendiente de la correlación entre la evolución del oxígeno y $F_{v} / F_{m}$ fue menor que 1 (aun cuando es contradictorio con este resultado que $s_{\mathrm{OE}}$ sea más alta en el tratamiento PAB que en los otros tratamientos en esta alga). Contrariarmente, se encontró que el grado de inhibición difirió en Chaetoceros sp. y Amphidinium sp. entre los tratamientos $\mathrm{PA}$ y $\mathrm{PAB}$, con menor inhibición en el tratamiento PA, mientras que las constantes de tiempo fueron similares en ambos tratamientos. Por ello, es posible que en estas algas hayan operado los mismos mecanismos de reparación concernientes a la fotosíntesis en ambos tratamientos. Esto sugiere una concurrente similaridad en las causas que indujeron la fotoinhibición, tal que los efectos de UV-A habrían sido aumentados en el tratamiento PAB por la irradiancia adicional debida a las longitudes de onda de UV-B. De aquí que en la inhibición de la fotosíntesis en 


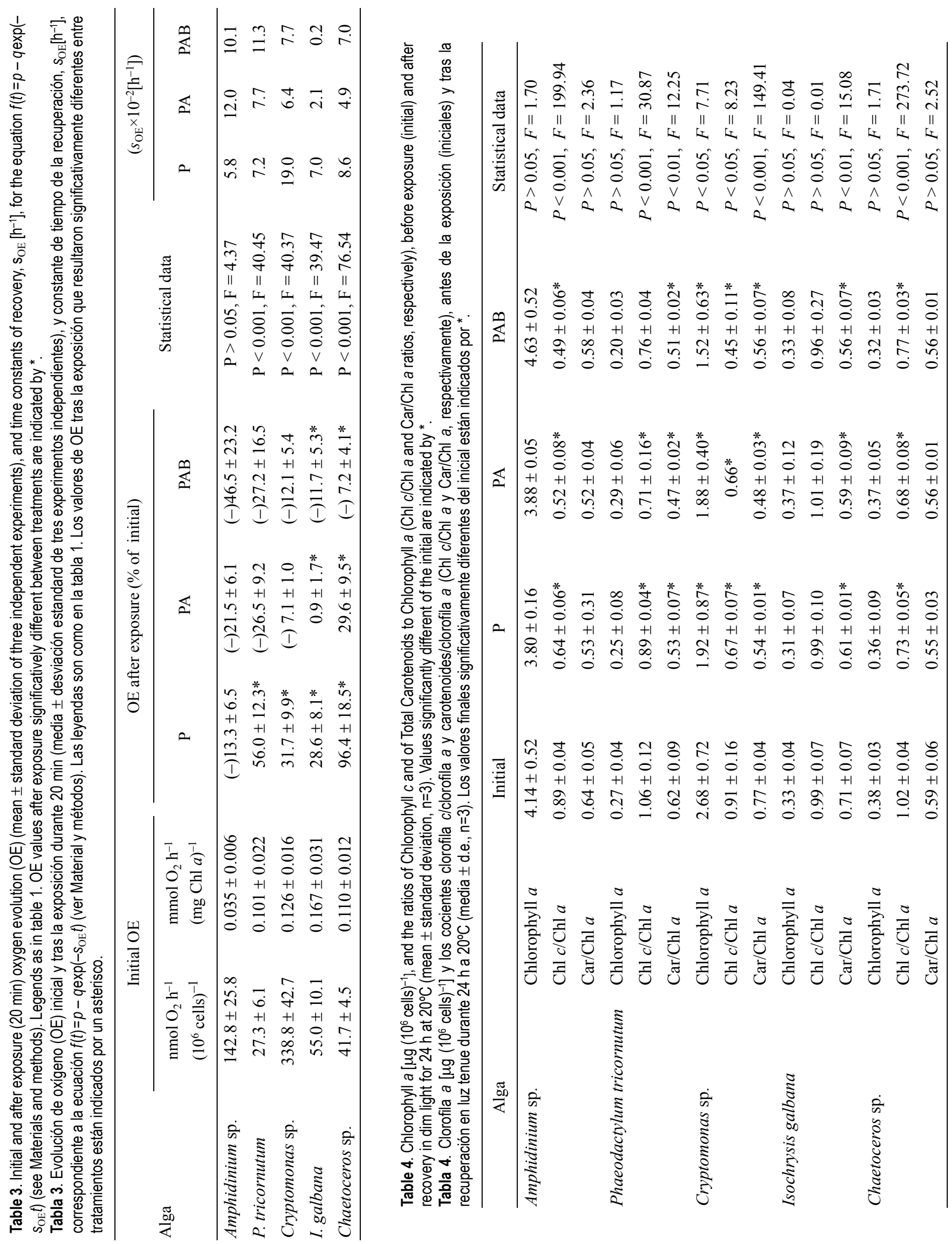


PAB-treatments in $P$. tricornutum and I. galbana, time constants of recovery increased significantly when UV-B was removed. An additional factor is therefore assumed to contribute to photoinhibition in the PAB-treatment compared to the PA-treatment in these algae. Damage to photosystem II (PSII) (Strid et al. 1994), along with damage to Rubisco (ribulose1,5-biphosphate-carboxylase/oxygenase) (Nogués and Baker, $1995)$ is likely involved in photoinhibition in these algae after exposure to UV-A+UV-B, but only damage to PSII when UV$\mathrm{B}$ was excluded. Impairment of the enzymes involved in the dark reactions of photosynthesis in P. tricornutum is also sustained by the fact that the slope of the correlation between oxygen evolution and $F_{v} / F_{m}$ was less than 1 (although it is contradictory to this result that $s_{\mathrm{OE}}$ was higher in the PAB-treatment than in the other treatments in this alga). Conversely, the extent of inhibition was found to differ in Chaetoceros sp. and Amphidium sp. between the PA- and PAB-treatments, with less photoinhibition in the PA-treatment, while the time constants were similar in both treatments. Therefore, the same repair mechanisms concerning photosynthesis have possibly operated in these latter algae in both treatments. This suggests concurrent similarity of causes inducing photoinhibition, whereby effects of UV-A were enhanced in the PAB-treatment by additional irradiance due to the UV-B wavelengths. Hence, damage to the donor side of PSII, which has been shown to be the primary cause of inhibition by UVR (Renger et al., 1989), is likely involved in photosynthesis inhibition in Chaetoceros sp. and Amphidinium sp. No significant differences were found between the PA- and PAB-treatments in Cryptomonas sp. in relation to the extent of inhibition, recovery time course and time constants. Consequently, causes of inhibition and recovery mechanisms operating in this alga are likely the same following exposure to UV-A and UV-A+UV-B, with UV-A apparently being the main promoter of photoinhibition in it. Light harvesting in Cryptomonas sp. is strongly dependent on phycobilin-protein complexes, which absorb within the UV-A and UV-B wavelength ranges, and which have been shown to be specially susceptible of damage by UVR, at least in cyanobacteria (Aráoz and Häder, 1997). In addition, Cryptomonas sp. exhibited the largest decrease in the ratios of Chl $c$ and carotenoids to Chl $a$, along with Chl $a$ itself. It is therefore suggested that photosynthesis inhibition by UVR in this alga is likely bound to the impairment of the structure of the photosynthetic apparatus by destruction of the phycobilin-protein complexes and of accessory pigments. However, because no filter was used in the PAB-treatment, it is not excluded that the additional PAR irradiance in this treatment, as compared to the other treatments (about 15\%), could have significantly contributed to the extent of photoinhibition, that is, the extent to which any given component is affected.

Exclusion of UVR (P-treatment) led to lower photoinhibition in all algae, which is in agreement with different mechanisms of photosynthesis inhibition involved following PAR and UVR exposures (Strid et al., 1994). However, time constants of recovery in Amphidinium sp. were the same for
Chaetoceros sp. y Amphidinium sp. probablemente está implicado el daño a PSII al nivel de las plastoquinonas, el cual ha sido mostrado como la causa fundamental de inhibición por UVR (Renger et al., 1989). No se encontraron diferencias significativas entre los tratamientos PA y PAB en Cryptomonas sp., en relación al alcance de la inhibición, el curso temporal de recuperación y las constantes de tiempo. Consecuentemente, las causas de la inhibición y los mecanismos de recuperación operantes en este alga son probablemente los mismos tras la exposición a UV-A y UV-A+UV-B, siendo aparentemente en ella UV-A el principal promotor de la fotoinhibición. La captación de luz en Cryptomonas sp. depende mucho de los complejos proteína-ficobilinas, los cuales absorben dentro de los rangos de longitudes de onda de UV-A y UV-B, y los cuales han sido mostrados como especialmente susceptibles de daño por UVR, al menos en cianobacterias (Aráoz y Häder, 1997). Adicionalmente, Cryptomonas sp. exhibió el mayor descenso en los cocientes $\mathrm{Chl} c / \mathrm{Chl} a \mathrm{y}$ carotenoides/Chl $a$, junto a la misma Chl $a$. Se sugiere por tanto que la inhibición de la fotosíntesis por UVR en esta microalga está probablemente ligada al deterioro de la estructura del aparato fotosintético por la destrucción de los complejos proteína-ficobilina y los pigmentos accesorios. Sin embargo, dado que no se usaron filtros en él, no se excluye que la irradiancia PAR adicional en el tratamiento $\mathrm{PAB}$, en comparación con los otros tratamientos (sobre un $15 \%$ ), pueda haber contribuido significativamente al grado de fotoinhibición, esto es, al grado en que cada componente es afectado.

La exclusión de UVR (tratamiento P) condujo a una fotoinhibición menor en todas las algas, lo cual está de acuerdo con los diferentes mecanismos de inhibición de la fotosíntesis implicados tras la exposición a PAR y UVR (Strid et al., 1994). Sin embargo, las constantes de tiempo de recuperación fueron las mismas para el tratamiento $\mathrm{P}$ que para los tratamientos PA y PAB en Amphidinium sp. Los mismos mecanismos de reparación pueden por tanto haber operado en este alga tras la inhibición de la fotosíntesis por PAR ó UVR. Este hecho sugiere en Amphidinium sp. un umbral de inhibición que habría sido ya superado por la propia radiación PAR. La constante de tiempo de $P$. tricornutum para el tratamiento $\mathrm{P}$, en cambio, aumentó substancialmente en comparación a las constantes de tiempo para los otros tratamientos, mostrando este alga así una notable capacidad para la recuperación tras la inhibición por PAR.

En general, el patrón de las constantes de tiempo de recuperación de la evolución del oxígeno $\left(s_{\mathrm{OE}}\right)$ fue algo diferente al patrón de las constantes de tiempo de recuperación de $F_{v} / F_{m}$, en particular para Amphidinium sp. y P. tricornutum. No obstante, ya que la evolución de oxígeno mostró una dependencia positiva de $F_{v} / F_{m}$ con una pendiente $>1$, es probable que la fotosíntesis haya estado limitada principalmente por la inhibición del flujo de electrones en PSII en todas las algas salvo, quizás, en $P$. tricornutum (pendiente < 1) (Nogués y Baker, 1995). En el caso de I. galbana tampoco debe descartarse daño al DNA en el tratamiento PAB.

La densidad celular no se vio afectada negativamente en 
the P-treatment as for the PA- and PAB-treatments. The same repair mechanisms may thereby have operated in this alga following inhibition of photosynthesis by PAR or UVR. This fact suggests an inhibition threshold in Amphidinium sp. that would have already been surpassed by PAR radiation itself. Time constant for P. tricornutum in the P-treatment was, in contrast, substantially enhanced in comparison to the time constants for the other treatments, thus showing a notable capability for recovery of this alga after inhibition by high PAR.

In general, the pattern of recovery time constants of oxygen evolution $\left(s_{\mathrm{OE}}\right)$ was somewhat different to the pattern of recovery time constants of $F_{v} / F_{m}$, in particular for Amphidinium sp. and P. tricornutum. Nonetheless, since oxygen evolution showed a positive dependence on $F_{v} / F_{m}$ with slope $>1$, photosynthesis is likely to have been mainly limited by inhibition of the electron flow at PSII in all the algae except, perhaps, in P. tricornutum (slope $<1$, Nogués and Baker, 1995). Damage to DNA in the PAB-treatment should also not be ruled out in I. galbana.

Cell density was not negatively affected in any of the algae, and increases in cell density at the end of the recovery period were even significant in P. tricornutum and I. galbana. Karentz et al. (1994) also reported no significant differences in growth between exposed and non-exposed samples of phytoplankton to UVR in an exclusion experiment. Therefore, our results are in agreement with those of Villafañe et al. (1995) in that strong inhibition of photosynthesis can not correlate with reduction of cell density, in particular when photoinhibion stems from short-term exposure.

Even though not all the algae were affected to the same extent, $\mathrm{Chl} c$ and carotenoids underwent a larger reduction than $\mathrm{Chl} a$, this result being in agreement with those previously shown in the literature (Häder and Worrest, 1991; Häberling and Häder, 1992) about the greater susceptibility of $\mathrm{Chl} c$ and carotenoids to bleaching than $\mathrm{Chl} a$. The reduction in the $\mathrm{Chl} c /$ $\mathrm{Chl} a$ and $\mathrm{Car} / \mathrm{Chl} a$ ratios may indicate a partial damage to the structure of the photosynthetic apparatus, which may have contributed to photoinhibition in almost all algae, even though only in Cryptomonas sp. it seems to have played a significant role (see above).

In conclusion, photoinhibition measured in natural populations is likely to depend on species composition and their relative abundance (Helbling et al., 1992), but our results show that phytoplanktonic species tolerance to UVR is also dependent on the capability for recovery, which may not correlate with the sensitivity to inhibition (Roos and Vincent, 1998). The composition of the photosynthetic apparatus may explain, at least in part, the differential sensitivity between microalgae, but other factors related to efficiency of the repair mechanisms are likely more determinant.

\section{Acknowledgements}

This work was financed by the Spanish Ministry of Education through the Commission of Science and Technology ninguna de las algas, e incluso hubo un aumento significativo de la densidad celular al final del periodo de recuperación en $P$. tricornutum e I. galbana. Karentz et al. (1994) también mostraron que no había diferencias significativas en el crecimiento entre muestras de fitoplancton expuestas y no expuestas a UVR en un experimento de exclusión selectiva de longitudes de onda. Por lo tanto, nuestros resultados están de acuerdo con los de Villafañe et al. (1995), en el sentido de que una inhibición profunda de la fotosíntesis puede no estar correlacionada con la reducción de la densidad celular, en particular cuando la fotoinhibición se origina por exposiciones breves.

Aún cuando no todas las algas fueron afectadas al mismo nivel, la $\mathrm{Chl} c$ y los carotenoides soportaron una reducción mayor que la Chl $a$, estando este resultado de acuerdo con lo mostrado previamente en la literatura (Häder y Worrest, 1991; Häberling y Häder, 1992) sobre una mayor susceptibilidad de la Chl $c$ y los carotenoides a la decoloración que la de Chl $a$. La reducción de los cocientes $\mathrm{Chl} c / \mathrm{Chl} a \mathrm{y} \mathrm{Car/Chl} a$ puede ser indicativa de un daño parcial a la estructura del aparato fotosintético, el cual puede haber contribuido a la fotoinhibición en casi todas las algas, aún cuando solamente en Cryptomonas sp. parece haber jugado un papel significativo (ver más atrás).

En conclusión, la fotoinhibición medida en poblaciones naturales depende probablemente de la composición de especies y su abundancia relativa (Helbling et al., 1992), pero nuestros resultados muestran que la tolerancia a UVR de las especies fitoplanctónicas depende también de la capacidad de recuperación, la cual puede no correlacionarse con la sensibilidad a la inhibición (Roos y Vincent, 1998). La composición del aparato fotosintético puede explicar, al menos en parte, la diferente sensibilidad entre las microalgas, pero otros factores relacionados con la eficiencia de los mecanismos de reparación son probablemente más determinantes.

\section{Agradecimientos}

Este trabajo fue financiado por el Ministerio de Educación Español a través de la Comisión de Ciencia y Tecnología (CICYT), proyecto AMB97-1021-CO2-02. Los autores agradecen a José L. Palazón su ayuda en el análisis estadístico.

Traducido al español por los autores.

(CICYT), project AMB97-1021-CO2-02. The authors thank Jose L. Palazón for helping with the statistical analysis.

\section{References}

Aráoz, R. and Häder, D.P. (1997). Ultraviolet radiation induces both degradation and synthesis of phycobilisomes in Nostoc sp.: a spectroscopic and biochemical approach. FEMS Microbiol. Ecol., 23: 301-313.

Behrenfeld, M.J., Chapman, J.W., Hardy, J.T. and Lee, H. (1993). Is there a common response to ultraviolet-B radiation by marine phytoplankton?. Mar. Ecol. Prog. Ser., 102: 59-68. 
Cullen, J. J., Neale, P. J. and Lesser, M. P. (1992). Biological weighting function for the inhibition of photosynthesis by ultraviolet radiation. Science, 258: 646-50.

Garcia-Pichel, F. (1996). The absorption of ultraviolet radiation by microalgae: simple optics and photobiological implications. Sci. Mar., 60: 63-79.

Guillard, R.R.L. and Ryther, J.H. (1962). Studies on marine planktonic diatoms. I. Cyclotella nana Hustedt and Denotula confervacea (Cleve) Gran. Can. J. Microbiol., 8: 229-39.

Häberlein, A. and Häder, D.P. (1992). UV effects on photosynthetic oxygen production and chromoprotein composition in a freshwater flagellate Cryptomonas. Acta Protozool., 31: 85-92.

Häder, D.P. (1993). Risks of enhanced solar ultraviolet radiation for aquatic ecosystems. Progr. Phycol. Res., 9: 1-45.

Häder, D.P. and Worrest, M. A. (1991). Effects of enhanced solar ultraviolet radiation on aquatic ecosystems. Photochem. Photobiol., 53: 717-25.

Häder, D.P., Worrest, R.C. and Kumar, H.D. (1991). Aquatic ecosystems. UNEP Environmental Effects Panel Report, pp. 3340.

Helbling, E.W., Villafañe, V., Ferrario, M. and Holm-Hansen, O. (1992). Impact of natural ultraviolet radiation on rates of photosynthesis and on specific marine phytoplankton species. Mar. Ecol. Prog. Ser., 80: 89-100.

Helbling, E.W., Villafañe, V. and Holm-Hansen, O. (1994). Effects of ultraviolet radiation on antarctic marine phytoplankton photosynthesis with particular attention to the influence of mixing. In: C.S. Weiler, and P.A. Penhale (eds.), Ultraviolet Radiation in Antarctica: Measurements and Biological Effects. American Geophysical Union, Washington, DC, pp. 93-110.

Hirosawa, T. and Miyachi, S. (1983). Effects of long-wavelength ultraviolet (UV-A) radiation on the growth of Anacystis nidulans. Plant Sci. Lett., 28: 291-298.

Jeffrey, S.W. and Haxo, F.T. (1968). Photosynthetic pigments of dinoflagellates (Zooxanthellae) from corals and clams. Biol. Bull., 135: 149-65.

Karentz, D., Cleaver, J.E. and Mitchell, D.L. (1991). Cell survival characteristics and molecular responses of Antarctic phytoplankton to ultraviolet-B radiation. J. Phycol., 27: 326-341.

Karentz, D., Bothwell, M.L., Coffin, R.B., Hanson, A., Herndl, G.J., Kilham, S.S., Lesser, M.P., Lindell, M., Moeller, R.E., Morris, D.P., Neale, P.J., Sanders, R.W., Weiler, C.S. and Wetzel, R.G. (1994). Impact of UV-B radiation on pelagic freshwater ecosystems: report of working group on bacteria and phytoplankton. Arch. Hydrobiol. Beih., 43: 31-69.

Neale, P.J. (1987). Algal photoinhibition and photosynthesis in the aquatic environment. In: D.J. Kyle, C.B. Osmond and C. J. Arntzen, (eds.), Photoinhibition. Elsevier, pp. 35-65.

Neale, P.J., Cullen, J.J. and Davis, R.F. (1998). Inhibition of marine photosynthesis by ultraviolet radiation: Variable sensitivity of phytoplankton in the Weddell-Scotia Confluence during the austral spring. Limnol. Oceanogr., 43: 433-48.

Nogués, S. and Baker, N.K. (1995). Evaluation of the role of damage to photosystem II in the inhibition of $\mathrm{CO}_{2}$ assimilation in pea leaves on exposure to UV-B radiation. Plant Cell Environ., 18: 781-787.

Owens, T.G. (1986). Light-harvesting function in the diatom Phaeodactylum tricornutum. II. Distribution of excitation energy between photosystems. Plant Physiol., 80: 739-746.

Prézelin, B.B., Boucher, N.B. and Smith, R.C. (1994). Marine primary production under the influence of the Antarctic ozone hole: Icecolors `90. In: C.S. Weiler, and P.A. Penhale (eds.), Ultraviolet radiation and biological research in Antarctica. AGU, pp. 159186.

Quesada, A., Mouget, J.L. and Vincent, W.F. (1995). Growth of Antarctic cyanobacteria under ultraviolet radiation: UV-A counteracts UV-B inhibition. J. Phycol., 31: 242-248.

Roos, J.C. and Vincent, W.F. (1998). Temperature dependence of UV radiation effects on antartic cyanobacteria. J. Phycol., 34: 118125.

Schreiber, U., Schliwa, U. and Bilger, W. (1986). Continuous recording of photochemical and non-photochemical chlorophyll fluorescence quenching with a new type of modulation fluorometer. Phostosyn. Res., 10: 51-62.

Schreiber, U., Bilger, W. and Neubauer, C. (1994). Chlorophyll fluorescence as a nonintrusive indicator for rapid assessment of in vivo photosynthesis. In: E.D. Schulze, and M.M. Caldwell, (eds.), Ecophysiology of Photosynthesis. Springer, Berlin, pp. 49-70.

Smith, R.C. and Cullen, J.J. (1995). Effects of UV radiation on phytoplankton. Rev. Geophys., 33: 1211-1223.

Smith, R.C., Prèzelin, B.B., Baker, K.S., Bidigare, R.R., Boucher, N. P., Coley, T., Karentz, D., MacIntyre, S., Matlick, H.A., Menzies, D., Ondrusek, M., Wan, Z. and Waters, K.J. (1992). Ozone depletion: Ultraviolet radiation and phytoplankton biology in Antarctic waters. Science, 255: 952-959.

Strickland, J.D.H. and Parsons, T.R. (1968). A practical handbook of seawater analysis. Bull. Fish. Res. Bd. Canada, 167, 311 pp.

Strid, A., Chow, W.S. and Anderson, J.M. (1994). UV-B damage and protection at the molecular level in plants. Photosyn. Res., 39: 475-489.

Talling, J.F. and Driver, D. (1963). Some problems in the estimation of chlorophyll- $a$ in phytoplankton. Proc., Conference of Primary Productivity Measurement, Marine and Freshwater, Hawaii, 1961. U.S. Atomic Energy Comm. TID-7633, pp. 142-146.

Vincent, W.F. and Roy, S. (1993). Solar ultraviolet-B radiation and aquatic primary production: damage, protection, and recovery. Environ. Rev., 1: 1-12.

Villafañe, V.E., Helbling, E.W., Holm-Hansen, O. and Chalker, B.E. (1995). Acclimatization of Antarctic natural phytoplankton assemblages when exposed to solar ultraviolet radiation. J. Plankton Res., 17(12): 2295-2306.

Williamson, C.E. (1995). What role does UV-B radiation play in freshwater ecosystems?. Limnol. Oceanogr., 40: 386-392.

Worrest, R.C. and Häder, D.P. (1997). Overview of the Effects of Increased Solar UV on Aquatic Microorganisms. Photochem. Photobiol., 65: 257-259. 